\title{
Culicoides monitoring in Belgium in 2011: analysis of spatiotemporal abundance, species diversity and Schmallenberg virus detection
}

\author{
N. D E R E G E E ${ }^{1}$, R. DE DEKE N ${ }^{2}$, C. FA S S T T E ${ }^{3}$, B. L O S S O N ${ }^{4}$, \\ I. D E B L A U W E ${ }^{2}$, M. M A D D E R ${ }^{2,5}$, P. VA N T I E G E M ${ }^{2}$, M. TO M M E ${ }^{3}$, \\ F. S MEE T S ${ }^{4}$ and A. B. C A Y ${ }^{1}$ \\ ${ }^{1}$ Operational Direction Viral Diseases, Veterinary and Agrochemical Research Centre (CODA-CERVA), Brussels, Belgium, \\ ${ }^{2}$ Department of Biomedical Sciences, Institute of Tropical Medicine, Antwerp, Belgium, ${ }^{3}$ Plant Protection and Ecotoxicology, Life \\ Science Department, Walloon Agricultural Research Centre (CRA-W), Gembloux, Belgium, ${ }^{4}$ Department of Infectious and Parasitic \\ Diseases, Faculty of Veterinary Medicine, University of Liège, Liège, Belgium and ${ }^{5}$ Department of Veterinary Tropical Diseases, \\ Faculty of Veterinary Science, University of Pretoria, Pretoria, South Africa
}

\begin{abstract}
In 2011, Culicoides (Diptera: Ceratopogonidae) were collected at 16 locations covering four regions of Belgium with Onderstepoort Veterinary Institute (OVI) traps and at two locations with Rothamsted suction traps (RSTs). Quantification of the collections and morphological identification showed important variations in abundance and species diversity between individual collection sites, even for sites located in the same region. However, consistently higher numbers of Culicoides midges were collected at some sites compared with others. When species abundance and diversity were analysed at regional level, between-site variation disappeared. Overall, species belonging to the subgenus Avaritia together with Culicoides pulicaris (subgenus Culicoides) were the most abundant, accounting for $80 \%$ and $96 \%$ of all midges collected with RSTs and OVI traps, respectively. Culicoides were present during most of the year, with Culicoides obsoletus complex midges found from 9 February until 27 December. Real-time reverse-transcription polymerase chain reaction screening for Schmallenberg virus in the heads of collected midges resulted in the first detection of the virus in August 2011 and identified C. obsoletus complex, Culicoides chiopterus and Culicoides dewulfi midges as putative vector species. At Libramont in the south of Belgium, no positive pools were identified.
\end{abstract}

Key words. Culicoides, midges, monitoring, Schmallenberg virus, vector.

\section{Introduction}

Biting midges are small haematophagous Diptera belonging to the family Ceratopogonidae, genus Culicoides. Some species in this genus are known vectors of arboviruses like African horse sickness virus, Akabane virus (AKAV), bluetongue virus (BTV), epizootic haemorrhagic disease virus and equine encephalosis virus (Mellor et al., 2000; Johnson et al., 2012).
Immediately after the start of the BTV serotype 8 (BTV-8) outbreak in 2006 in central and northern Europe, several countries initiated Culicoides monitoring programmes to study the abundance, composition, dispersal and seasonal dynamics of these insects and to define vector-free periods (De Deken et al., 2008; Meiswinkel etal., 2008a, 2008b; Casati etal., 2009; Hoffmann etal., 2009; Hörbrand \& Geier, 2009; Kiel etal., 2009; Vorsprach etal., 2009; Berisha et al., 2010; Silbermayr

Correspondence: Nick De Regge, Operational Direction Viral Diseases, Veterinary and Agrochemical Research Centre (CODA-CERVA), Groeselenberg 99, 1180 Brussels, Belgium. Tel.: + 32237905 80; Fax: + 32237906 70; E-mail: nick.deregge@ coda-cerva.be 
Table 1. Culicoides trapping locations used in Belgium in 2011.

\begin{tabular}{|c|c|c|c|c|c|}
\hline Trap type & Location & Livestock & Trap position & Longitude, ${ }^{\circ} \mathrm{E}$ & Latitude, ${ }^{\circ} \mathrm{N}$ \\
\hline \multirow[t]{19}{*}{ OVI trap } & \multicolumn{5}{|l|}{ Antwerp } \\
\hline & Nijlen & Dairy cows & Stable & 4.693747 & 51.159744 \\
\hline & Nijlen & Horses & Stable & 4.687219 & 51.155171 \\
\hline & Varendonk & Dairy cows & Stable & 4.954160 & 51.085820 \\
\hline & Kessel & Horses, cattle, sheep, chickens & Meadow & 4.607064 & 51.154562 \\
\hline & Berlaar & Dairy cows & Stable & 4.665713 & 51.118610 \\
\hline & Olen & Cattle & Stable & 4.865726 & 51.151850 \\
\hline & Eindhout & Horses & Stable & 4.972531 & 51.086183 \\
\hline & Betekom & Sheep, deer, chickens & Meadow & 4.79206 & 51.00200 \\
\hline & \multicolumn{5}{|l|}{ Liège } \\
\hline & Verlaine & Dairy cows & Meadow & 5.379914 & 50.611208 \\
\hline & Boncelles & Horses & Stable & 5.554803 & 50.567739 \\
\hline & Sart Tilman & Cattle, sheep, goats, chickens, horses & Stable & 5.587336 & 50.576544 \\
\hline & Nandrin & Horses, cattle, pigs & Stable & 5.358419 & 50.528464 \\
\hline & Bettincourt & Chickens & Meadow & 5.236917 & 50.712872 \\
\hline & Gembloux & Cattle, sheep, pigs & Stable & 4.72662 & 50.56509 \\
\hline & \multicolumn{5}{|l|}{ Libramont } \\
\hline & Libramont & Sheep & Meadow & 5.35956 & 49.92881 \\
\hline & Libramont & Cattle & Meadow & 5.35636 & 49.92931 \\
\hline \multirow[t]{2}{*}{ RST } & Gembloux & None & Meadow & 4.70942 & 50.56294 \\
\hline & Libramont & Cattle, sheep & Meadow & 5.36082 & 49.92667 \\
\hline
\end{tabular}

OVI, Onderstepoort Veterinary Institute; RST, Rothamsted suction trap.

et al., 2011; Ander et al., 2012). Furthermore, midges collected during surveys conducted around this period were used to identify putative vector species, which led to the detection of BTV-8 in Culicoides obsoletus complex, Culicoides dewulfi, Culicoides chiopterus and Culicoides pulicaris (De Liberato et al., 2005; Savini etal., 2005; Mehlhorn etal., 2007; Meiswinkel etal., 2007; Dijkstra et al., 2008; Vanbinst et al., 2009). The oral susceptibility of Culicoides scoticus and vector competence of Culicoides sonorensis for BTV-8 have also been demonstrated (Carpenter et al., 2008a; Veronesi et al., 2013a).

In 2011, a new orthobunyavirus called Schmallenberg virus (SBV) (Hoffmann et al., 2012), which causes mild symptoms in adult cattle but severe congenital malformations in lambs, calves and goat kids, was identified. This virus spread rapidly over Europe after its emergence (Conraths et al., 2013; Doceul et al., 2013; European Food Safety Authority, 2013; Chaintoutis etal., 2014). Culicoides midges were suspected to be responsible for this fast spread of SBV because they are known vectors for several related viruses (e.g. AKAV) (St George et al., 1978; Al-Busaidy \& Mellor, 1991; Bryant et al., 2005; Yanase et al., 2005). Several studies using field-collected midges have detected SBV in C. obsoletus complex, C. chiopterus and C. dewulfi midges (De Regge etal., 2012; Rasmussen etal., 2012; Goffredo et al., 2013; Elbers et al., 2013a, 2013b; Larska et al., 2013a, 2013b) and a vector competence study has shown the replication and dissemination of SBV in C. sonorensis (Veronesi et al., 2013b).

In the present study, Culicoides collected at 16 sites dispersed over four regions in Belgium during 2011 were used to analyse potential differences in species abundance and diversity between individual collection sites and among regions. Furthermore, the collected midges were used to study several aspects of the epidemiology of SBV.

\section{Materials and methods}

\section{Culicoides trapping}

In 2011, Culicoides were collected with Onderstepoort Veterinary Institute (OVI) traps operated with $12-\mathrm{V}$ batteries (Venter etal., 2009) at 16 different locations (Table 1) covering four regions of Belgium (Fig. 1), including Antwerp (northeast), Liège (east), Gembloux (central) and Libramont (south). During January and February and July-September, Culicoides were collected every second week, whereas during March-June and October-December, weekly catches were performed. Collections were carried out on 41 collection dates. Numbers of collections at each location are shown in Table 2. Each collection with a blacklight trap comprised one night. Insects were retained in $60 \%$ ethanol. All OVI traps were installed outside in the immediate vicinity of stables $(<20 \mathrm{~m})$ or in meadows in which animals were present throughout the year (Table 1).

Culicoides were also collected at two sites [Gembloux and Libramont (Table 1)] with stationary Rothamsted suction traps (RSTs) (Macaulay et al., 1988) capturing Culicoides at a height of $12 \mathrm{~m}$. Trapping occurred continuously during 2011 and the traps were emptied almost daily (363 times at Gembloux and 323 times at Libramont). Trapped insects were stored in $80 \%$ ethanol.

\section{Morphological identification}

The biting midges were morphologically identified to species level under the microscope using the key of Delécolle (1985) and stored in $80 \%$ ethanol. Culicoides obsoletus sensu strictu (C.obsoletus s.s.) and C. scoticus collected at Antwerp were 


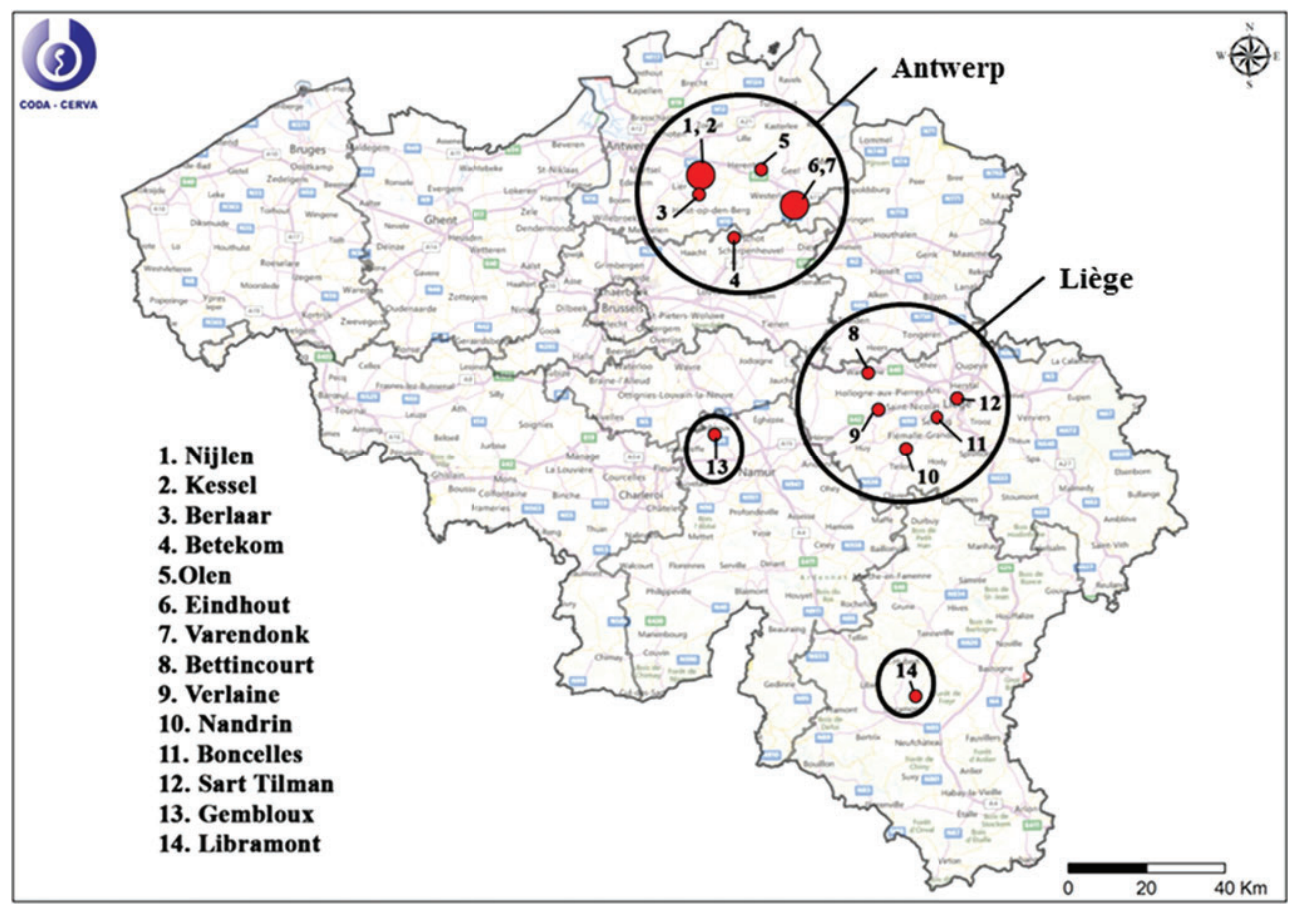

Fig. 1. Culicoides trapping locations in Belgium used during monitoring in 2011.

identified at species level, whereas collections of these two species at Liège, Gembloux and Libramont were grouped in the C. obsoletus complex. If collections exceeded 200 midges, 200 Culicoides were randomly selected and identified and numbers were extrapolated to the entire catch.

\section{rRT-PCR analysis of pools of Culicoides}

Species-specific pools containing a maximum of 25 heads of non-engorged parous females collected between July and October 2011 at Antwerp and Liège were tested for the presence of SBV. A similar approach was used for Culicoides collected between August and November at Gembloux and Libramont. Some additional pools of heads of blood-engorged female Culicoides were included.

The pools were analysed for the presence of the $\mathrm{S}$ and $\mathrm{L}$ segments of SBV by real-time reverse-transcription polymerase chain reaction (rRT-PCR) as described previously (De Regge et al., 2012). Pools positive for one or both segments were considered SBV-positive in the calculation of infection prevalence. To ensure that any proposal of putative vector species based solely on rRT-PCR data was conservative, only species in which both the $\mathrm{S}$ and $\mathrm{L}$ segments were detected were considered as putative vectors.

\section{Statistical analysis}

To determine whether certain locations or regions were more prone than others to support higher numbers of Culicoides collected, a ranking was made for each collection date whereby the location or region where the highest (mean) number of Culicoides were collected received the highest rank. This was done for all dates for which collections were available for each site or region and average rankings were calculated. Friedman's test was used to determine whether differences between ranks were significant. If significant differences were found, two-by-two comparisons of the locations were carried out using Wilcoxon post hoc tests. Bonferroni correction to compensate for the number of two-by-two comparisons was applied.

After the ranking of mean catch sizes per month for each location within a particular region, similar analyses were performed to determine whether the probability of collecting greater numbers of Culicoides was higher in particular months.

Differences between the ratios of SBV-positive pools collected at individual locations in the region of Liège were assessed using Fisher's exact test.

Statistical analyses were performed using IBM sPss Statistics for Windows Version 22.0 (IBM Corp., Armonk, NY, U.S.A.). $P$ values $<0.05$ were considered to be significant.

\section{Results}

Monitoring with OVI traps

Abundance and seasonality. A total of 382000 Culicoides were collected over 41 separate collection dates in 2011 using 16 OVI traps (Table 2). High variations in abundance were observed at each location throughout the year. Ranking of the different locations by abundance for each collection date showed 
Table 2. Culicoides abundances in 2011 in four regions of Belgium based on monitoring with 16 Onderstepoort Veterinary Institute (OVI) traps and two Rothamsted suction traps (RSTs).

\begin{tabular}{|c|c|c|c|c|c|c|c|c|}
\hline \multirow{2}{*}{$\begin{array}{l}\text { Trap type } \\
\text { OVI }\end{array}$} & \multirow{2}{*}{$\begin{array}{l}\text { Region } \\
\text { Antwerp }\end{array}$} & Location & \multicolumn{2}{|c|}{$\begin{array}{l}\text { Total number } \\
\text { collected, } n\end{array}$} & \multirow[t]{2}{*}{$\begin{array}{l}\text { Collections, } \\
n\end{array}$} & \multirow{2}{*}{$\begin{array}{l}\begin{array}{l}\text { Catch, } \\
\text { mean } \pm \text { SD }\end{array} \\
184 \pm 652\end{array}$} & \multirow[t]{2}{*}{$\begin{array}{l}\text { Average } \\
\text { intra-region } \\
\text { rank }\end{array}$} & \multirow{2}{*}{$\begin{array}{l}\begin{array}{l}\text { Average inter-region } \\
\text { rank based on } \\
\text { mean catch }\end{array} \\
2.5^{\mathrm{a}}\end{array}$} \\
\hline & & & Total & 58105 & & & & \\
\hline & & Nijlen & & 1824 & 38 & $48 \pm 87$ & $3.2^{\mathrm{a}}$ & \\
\hline & & Varendonk & & 15001 & 40 & $375 \pm 1415$ & $5.0^{\mathrm{b}}$ & \\
\hline & & Kessel & & 460 & 40 & $12 \pm 25$ & $2.7^{\mathrm{a}}$ & \\
\hline & & Berlaar & & 12180 & 40 & $305 \pm 603$ & $6.0^{\mathrm{b}}$ & \\
\hline & & Nijlen, manege & & 1096 & 40 & $27 \pm 76$ & $2.9^{\mathrm{a}}$ & \\
\hline & & Olen & & 7209 & 40 & $180 \pm 372$ & $5.0^{\mathrm{b}}$ & \\
\hline & & Eindhout & & 3591 & 40 & $90 \pm 186$ & $5.3^{\mathrm{b}}$ & \\
\hline & & Betekom & & 16744 & 38 & $441 \pm 845$ & $6.0^{\mathrm{b}}$ & \\
\hline & Liège & & Total & 218854 & & $1128 \pm 3097$ & & $3.2^{\mathrm{b}}$ \\
\hline & & Verlaine & & 6453 & 40 & $161 \pm 285$ & $2.4^{\mathrm{a}}$ & \\
\hline & & Boncelles & & 47534 & 40 & $1188 \pm 2324$ & $3.7^{\mathrm{b}}$ & \\
\hline & & Sart Tilman & & 58979 & 40 & $1474 \pm 2612$ & $3.6^{\mathrm{b}}$ & \\
\hline & & Nandrin & & 102865 & 37 & $2780 \pm 5741$ & $3.6^{\mathrm{b}}$ & \\
\hline & & Bettincourt & & 3023 & 37 & $82 \pm 153$ & $1.8^{\mathrm{a}}$ & \\
\hline & Gembloux & & & 20407 & 38 & $537 \pm 1356$ & & $1.9^{\mathrm{a}, \mathrm{b}}$ \\
\hline & Libramont & & Total & 84661 & & $1209 \pm 4171$ & & $2.4^{\mathrm{a}, \mathrm{b}}$ \\
\hline & & Libramont-sheep & & 66942 & 35 & $1913 \pm 5771$ & $1.9^{\mathrm{b}}$ & \\
\hline & & Libramont-cow & & 17719 & 35 & $506 \pm 994$ & $1.1^{\mathrm{a}}$ & \\
\hline RST & Gembloux & & & 1137 & 363 & $3 \pm 5$ & - & - \\
\hline & Libramont & & & 6410 & 323 & $20 \pm 31$ & - & - \\
\hline
\end{tabular}

Locations or regions with the same superscript letter did not significantly differ in two-by-two comparisons using Wilcoxon post hoc tests subsequent to findings of significant differences using Friedman's test.

$\mathrm{SD}$, standard deviation.

Berlaar and Betekom to have the highest average rankings in the region of Antwerp (Friedman's test, $P<0.0001$ ). No significant differences in the probability to collect high numbers between these sites and Olen, Eindhout and Varendonk were found. In contrast, the probability to collect high numbers was lower at Nijlen, Nijlen Manege and Kessel. At Liège (Friedman test, $P<0.0001$ ), the collection sites of Boncelles, Sart Tilman and Nandrin provided significantly higher probabilities to collect high numbers than Verlaine and Bettincourt. When a similar analysis was done based on mean catch sizes of each region, significant differences in average ranking were found (Friedman test, $P<0.0001$ ) and two-by-two comparisons showed that the probability to collect high numbers was significantly higher in Liège than in Antwerp. Mean numbers per collection (Fig. 2) were clearly higher in the months of April-November than during December-March, indicating that the probability of obtaining a more abundant catch is higher during spring, summer and autumn. This is reflected in the higher average ranking of these months in a ranking of mean catch size by month (data not shown). Despite the reported extensive individual variation, high numbers of Culicoides were collected in all four regions during weeks 19 and 34 (data not shown).

Species diversity. Forty Culicoides species were identified in the OVI trap collections during 2011 (Table 3). Culicoides obsoletus and C. scoticus, which together accounted for $86 \%$ of individuals, were the most abundant species to be collected in Belgium. Other prominent species were C. dewulfi (5\%) and C. chiopterus (3\%), making the Avaritia the dominant subgenus, covering $94 \%$ of all individuals. Culicoides pulicaris (2\%) was also relatively abundant. The other 35 species together accounted for about $4 \%$ of the total collection.

Important variation in species diversity was found between the individual collection sites (Table 3). Although C. obsoletus/scoticus represented the most prominent species at all locations, their relative abundance ranged from $38 \%$ to $96 \%$. Interestingly, some species that were absent or present in low numbers at most locations were highly abundant at others. For example, Culicoides kibunensis accounted for $31 \%$ of collections at Verlaine, Culicoides punctatus represented $10 \%$ of midges caught at Nijlen and Culicoides nubeculosus represented $9 \%$ of midges trapped at Betekom. However, when species diversity was examined at regional level (Table 3), relative abundances did not differ significantly between regions.

\section{Monitoring with RST traps}

Using RSTs, totals of 1137 and 6410 Culicoides were collected at Gembloux and Libramont, respectively, in 2011 (Table 2). In total, 29 species were collected by RSTs (Table 4). Except for Culicoides riouxi, all species were also collected with OVI traps. A clear difference in species composition between RST and OVI trap collections performed at nearby sites was observed (Table 3 ). Whereas $C$. obsoletus complex midges were 


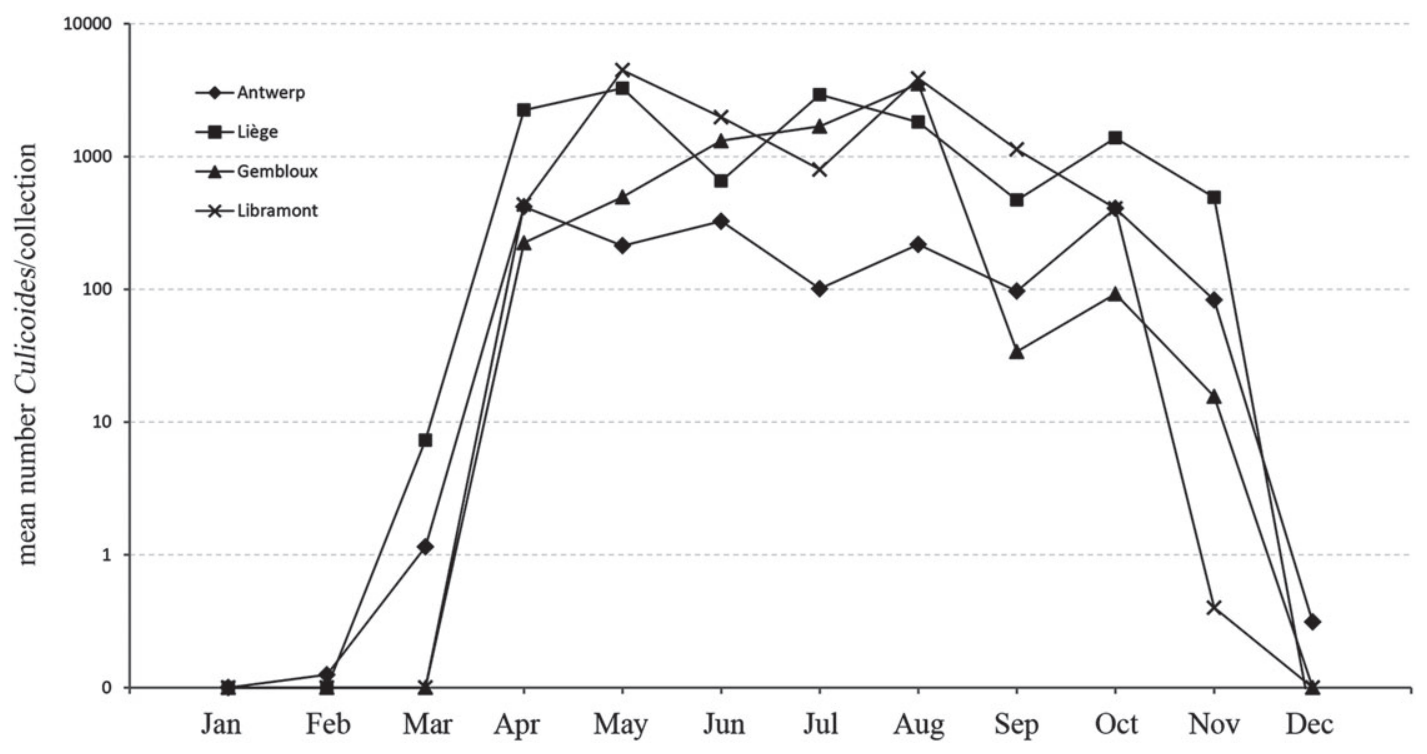

Fig. 2. Monthly spatiotemporal abundances of Culicoides in 2011 based on monitoring with 16 Onderstepoort Veterinary Institute (OVI) traps covering four regions of Belgium. Culicoides were monitored in Antwerp, Liège, Gembloux and Libramont with eight, five, one and two OVI traps, respectively. The mean number of Culicoides per collection is based on maximums of two (January, February, July, August, September), four (April, May, October, December) or five (March, June, November) collection dates in the respective month.

relatively less abundant in RST collections than in OVI trap collections (54\% vs. $80 \%$ and $35 \%$ vs. $92 \%$ in Gembloux and Libramont, respectively), C. pulicaris and C.chiopterus were relatively more abundant, indicating that species were more evenly distributed. Further, more species had relative abundances of $>1 \%$ in RST collections, certainly at Libramont.

\section{Phenology}

Species belonging to the subgenus Avaritia and some belonging to the subgenus Culicoides (C.pulicaris, C.punctatus, Culicoides lupicaris) were present during most of the year, ranging from periods of 7 or 8 months (April/May to November) to 11 months for C. obsoletus complex midges (Table 4). Although quite wide variation was observed for other species, most midges belonging to the subgenera Oecacta and Wirthomyia were found only for short periods, ranging from 1 week to 2 months (mostly in May and June).

When the presence of Culicoides across the different regions as determined by OVI trap collections is considered, it is apparent that the dates of first appearance are earliest in the northeast (15 February at Eindhout) and progress towards the east (1 March at Boncelles), the centre (31 March at Gembloux) and the south [5 April at Libramont (sheep)] (Table 5). In the central and southern regions, activity also seemed to stop a little earlier (mid-November) than in the northeast and east regions (end of November and beginning of December, respectively). At Betekom in the region of Antwerp, low numbers of C. obsoletus/scoticus were collected until the end of December (27 December).

Similarly to the OVI traps, the first and last species collected with both RSTs were $C$. obsoletus complex midges. Culicoides were collected with RSTs during a timeframe similar to those of OVI traps located in the near vicinity (Table 5), except that the last Culicoides were trapped at Gembloux on 6 December with an RST and on 8 November with an OVI trap. At Libramont, a single C.obsoletus complex midge was collected on 9 February, but the next individual was not collected until 30 March.

\section{Schmallenberg virus detection in pools of Culicoides heads}

The distribution of species-specific pools analysed for the presence of SBV reflected the species diversity of OVI trap collections. Most of the pools $(n=331)$ consisted of C. obsoletus/scoticus, followed by other species belonging to the Avaritia [C. dewulfi ( $n=41$ pools) and C. chiopterus $(n=42$ pools)]. Furthermore, several pools $(n=31)$ of $C$. pulicaris and a limited number of pools $(n=35)$ of non-abundant species were analysed (Fig. 3). A total of 480 pools representing 7305 midges were tested.

Some pools containing heads of C.obsoletus, C. dewulfi and C. chiopterus midges were found to be positive for both the $S$ and L segments of SBV and these species are therefore proposed as putative vector species for SBV. Only one pool of $C$. pulicaris was found positive for the $\mathrm{S}$ segment $(\mathrm{Ct}=37.9)$; positivity was not confirmed for the L segment.

The first $\mathrm{S}$ segment-positive pool was collected in the region of Liège (Boncelles) on 10 August and consisted of C. obsoletus complex midges (Table 6, Fig. 3). Of the pools collected in the same region, a further three of 58 collected in August and three of 39 pools collected in September were found to be $\mathrm{S}$ segment-positive; all of these consisted of C. obsoletus complex midges. This number increased substantially in October, with 


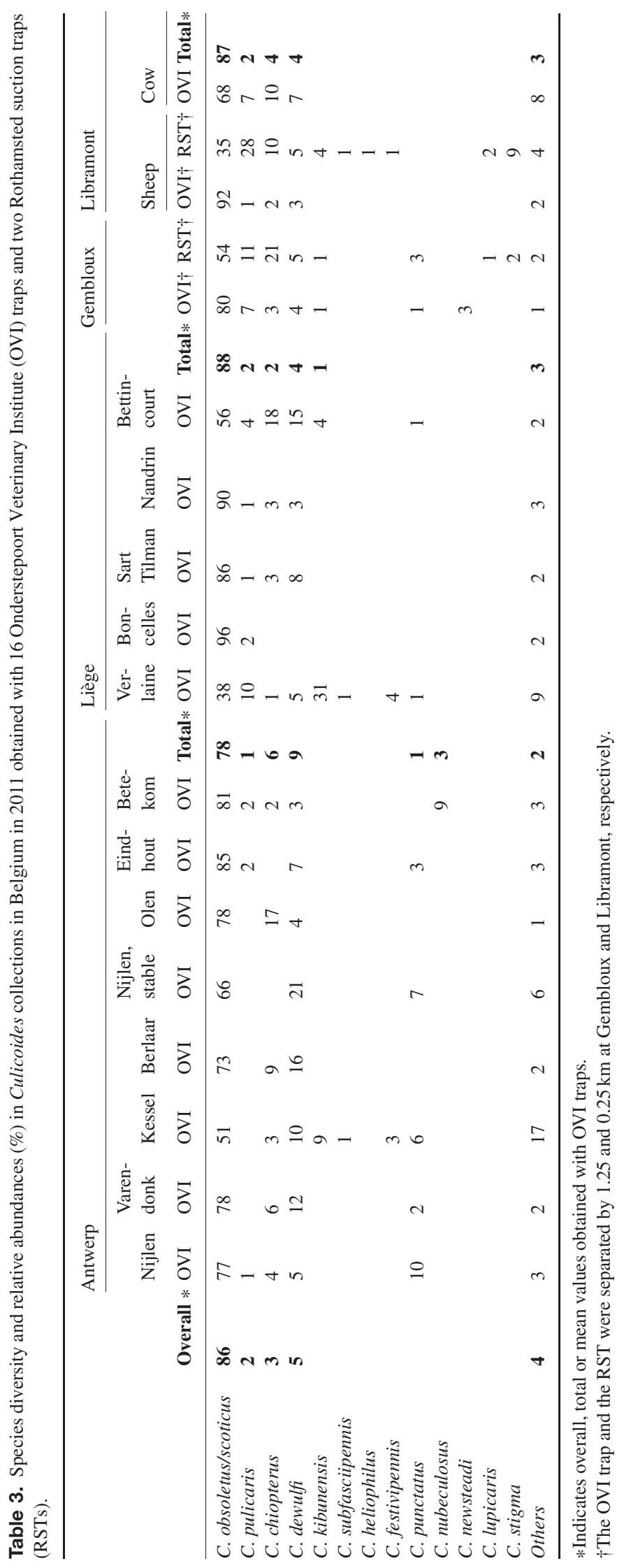

(c) 2015 The Royal Entomological Society, Medical and Veterinary Entomology, 29, 263-275 
Table 4. Location and time of first and last appearances of species identified during the Culicoides monitoring of 2011. Culicoides were collected with 16 Onderstepoort Veterinary Institute (OVI) traps and two Rothamsted suction traps (RSTs) in four regions of Belgium.

\begin{tabular}{|c|c|c|c|c|c|c|c|}
\hline Subgenus & Culicoides species & OVI & RST & $\begin{array}{l}\text { First } \\
\text { capture } \\
\text { date, } 2011\end{array}$ & $\begin{array}{l}\text { First } \\
\text { capture } \\
\text { place }\end{array}$ & Last capture place & $\begin{array}{l}\text { Last capture } \\
\text { date, } 2011\end{array}$ \\
\hline \multirow[t]{3}{*}{ Avaritia } & C. chiopterus & $\mathrm{x}$ & $\mathrm{x}$ & $02 / 04$ & Gembloux RST & Varendonk stable & $13 / 12$ \\
\hline & C. dewulfi & $\mathrm{x}$ & $\mathrm{x}$ & $13 / 04$ & Sart Tilman & Gembloux RST & $19 / 11$ \\
\hline & C. obsoletus and scoticus & $\mathrm{x}$ & $\mathrm{x}$ & $07-09 / 02$ & Libramont RST & Betekom & $27 / 12$ \\
\hline \multirow{3}{*}{ Beltranmyia } & C. circumscriptus & $\mathrm{x}$ & $\mathrm{x}$ & $19 / 04$ & Betekom & Nandrin & $04 / 11$ \\
\hline & C. manchuriensis & $\mathrm{x}$ & - & $19 / 04$ & Betekom & Olen & $24 / 08$ \\
\hline & C. salinarius & $\mathrm{x}$ & $\mathrm{x}$ & $21 / 04$ & Verlaine & Sart Tilman & $05 / 10$ \\
\hline \multirow[t]{7}{*}{ Culicoides } & C. deltus & $\mathrm{x}$ & $\mathrm{x}$ & $26 / 04$ & Libramont & Bettincourt & $04 / 11$ \\
\hline & C. grisescens & $\mathrm{x}$ & - & $15 / 06$ & Berlaar & Nijlen & $28 / 06$ \\
\hline & C. impunctatus & $\mathrm{x}$ & $\mathrm{x}$ & $10 / 05$ & $\begin{array}{l}\text { Libramont, Nijlen, Kessel, } \\
\text { Varendonk stable }\end{array}$ & Boncelles, Bettincourt & $10 / 08$ \\
\hline & C. lupicaris & $\mathrm{x}$ & $\mathrm{x}$ & $07 / 04$ & Gembloux RST & Gembloux & $08 / 11$ \\
\hline & C. newsteadi & $\mathrm{x}$ & $\mathrm{x}$ & $19 / 04$ & Varendonk & Varendonk & $12 / 10$ \\
\hline & C. pulicaris & $\mathrm{x}$ & $\mathrm{x}$ & $23 / 03$ & Nandrin & Boncelles, Nandrin & $18 / 11$ \\
\hline & C. punctatus & $\mathrm{x}$ & $\mathrm{x}$ & $29 / 03$ & Varendonk & Bettincourt & $30 / 11$ \\
\hline \multirow[t]{5}{*}{ Monoculicoides } & C. nubeculosus & $\mathrm{x}$ & $\mathrm{x}$ & $13 / 04$ & Bettincourt & Varendonk, Betekom & $12 / 10$ \\
\hline & C. parroti & $\mathrm{x}$ & $\mathrm{x}$ & $21 / 06$ & Gembloux RST & Bettincourt & $05 / 10$ \\
\hline & C. puncticollis & $\mathrm{x}$ & - & $15 / 06$ & Varendonk & Varendonk & $20 / 09$ \\
\hline & C. riethi & $\mathrm{x}$ & $\mathrm{x}$ & $10 / 05$ & Bettincourt & Varendonk & $12 / 10$ \\
\hline & C. stigma & $\mathrm{x}$ & $\mathrm{x}$ & $07-14 / 04$ & Libramont RST & Libramont RST & $04-07 / 11$ \\
\hline \multirow[t]{14}{*}{ Oecacta } & C. alazanicus & $\mathrm{x}$ & - & $30 / 05$ & Verlaine & Varendonk stable, Betekom & $24 / 08$ \\
\hline & C. albicans & $\mathrm{x}$ & - & $19 / 04$ & Varendonk & Nandrin & $30 / 05$ \\
\hline & C. albihalteratus & $\mathrm{x}$ & - & $21 / 04$ & Verlaine & Verlaine, Sart Tilman, Nandrin & $30 / 05$ \\
\hline & C. brunnicans & $\mathrm{x}$ & $\mathrm{x}$ & $19 / 04$ & Berlaar, Betekom & Libramont RST & $10 / 06$ \\
\hline & C. clastrieri & $\mathrm{x}$ & - & $15 / 07$ & Verlaine & Verlaine & $15 / 07$ \\
\hline & C. festivipennis & $\mathrm{x}$ & $\mathrm{x}$ & $26 / 04$ & Varendonk, Betekom & Bettincourt & $04 / 11$ \\
\hline & C. furcillatus & $\mathrm{x}$ & - & $10 / 05$ & Sart Tilman & Varendonk & $12 / 10$ \\
\hline & C. heliophilus & $\mathrm{x}$ & $\mathrm{x}$ & $10 / 05$ & Sart Tilman, Libramont RST & Libramont RST & $20-23 / 07$ \\
\hline & C. kibunensis & $\mathrm{x}$ & $\mathrm{x}$ & $21 / 04$ & Verlaine & Verlaine & $25 / 09$ \\
\hline & C. pictipennis & $\mathrm{x}$ & $\mathrm{x}$ & $04 / 04$ & Berlaar & Verlaine & $22 / 06$ \\
\hline & C. poperinghensis & $\mathrm{x}$ & - & $19 / 04$ & Berlaar & Verlaine & $22 / 06$ \\
\hline & C. simulator & $\mathrm{x}$ & - & $18 / 05$ & Verlaine & Verlaine & $30 / 05$ \\
\hline & C. truncorum & $\mathrm{x}$ & - & $30 / 05$ & Sart Tilman, Nandrin & Sart Tilman, Nandrin & $30 / 05$ \\
\hline & C. vexans & $\mathrm{x}$ & $\mathrm{x}$ & $14 / 04$ & Gembloux RST & Gembloux & $21 / 06$ \\
\hline \multirow[t]{5}{*}{ Silvaticulicoides } & C. achrayi & $\mathrm{x}$ & $\mathrm{x}$ & $28 / 04$ & Sart Tilman & Varendonk, Varendonk stable & $02 / 11$ \\
\hline & C. fascipennis & $\mathrm{x}$ & $\mathrm{x}$ & $07 / 06$ & Libramont & Libramont RST & $15 / 09$ \\
\hline & C. pallidicornis & $\mathrm{x}$ & $\mathrm{x}$ & $08 / 05$ & Libramont RST & Libramont & $23 / 08$ \\
\hline & C. picturatus & $\mathrm{x}$ & - & $30 / 05$ & Verlaine, Sart Tilman & Bettincourt & $28 / 10$ \\
\hline & C. subfasciipennis & $\mathrm{x}$ & $\mathrm{x}$ & $10 / 05$ & Verlaine, Sart Tilman, Kessel & Libramont RST & $27 / 08$ \\
\hline \multirow{3}{*}{ Wirthomyia } & C. minutissimus & $\mathrm{x}$ & $\mathrm{x}$ & $06 / 05$ & Libramont RST & Gembloux RST & $11 / 07$ \\
\hline & C. riouxi & - & $\mathrm{x}$ & $27 / 05$ & Libramont RST & Libramont RST & $14 / 06$ \\
\hline & C. segnis & $\mathrm{x}$ & $\mathrm{x}$ & $26 / 04$ & Libramont & Libramont & $23 / 08$ \\
\hline
\end{tabular}

24 of 48 pools found to be $\mathrm{S}$ segment-positive (19 pools of C. obsoletus complex, four pools of C.dewulfi and one pool of C.chiopterus). In the region of Antwerp, four (three of C.obsoletus and one of C.pulicaris) of 36 pools collected in September and one (C. dewulfi) of 68 pools collected in October were found to be positive for the S segment. In Gembloux, two of 14 pools collected in October were $\mathrm{S}$ segment-positive. In the south of Belgium, at Libramont, no positive pools were found, indicating a lower circulation of SBV.

The $\mathrm{Ct}$ values for the rRT-PCR detecting the $\mathrm{S}$ segment varied between 26.6 and 38.5 in the positive pools (Table 6). Most of the pools with a $\mathrm{Ct}$ value of $>35$ for the $\mathrm{S}$ segment were not found positive for the L segment by rRT-PCR.
An analysis of data for the region of Liège, where $31 \mathrm{~S}$ segment-positive pools were found during August-October 2011, showed that none of the individual locations seemed more suitable than others for collections of SBV-positive midges (Fisher's exact test, $P=0.559$ ) (Table 7).

\section{Discussion}

The Culicoides survey of 2011 showed that midges belonging to the subgenus Avaritia (C.obsoletus/scoticus, C. dewulfi, C. chiopterus), together with C. pulicaris (subgenus Culicoides), represent the most abundant and widely distributed species 


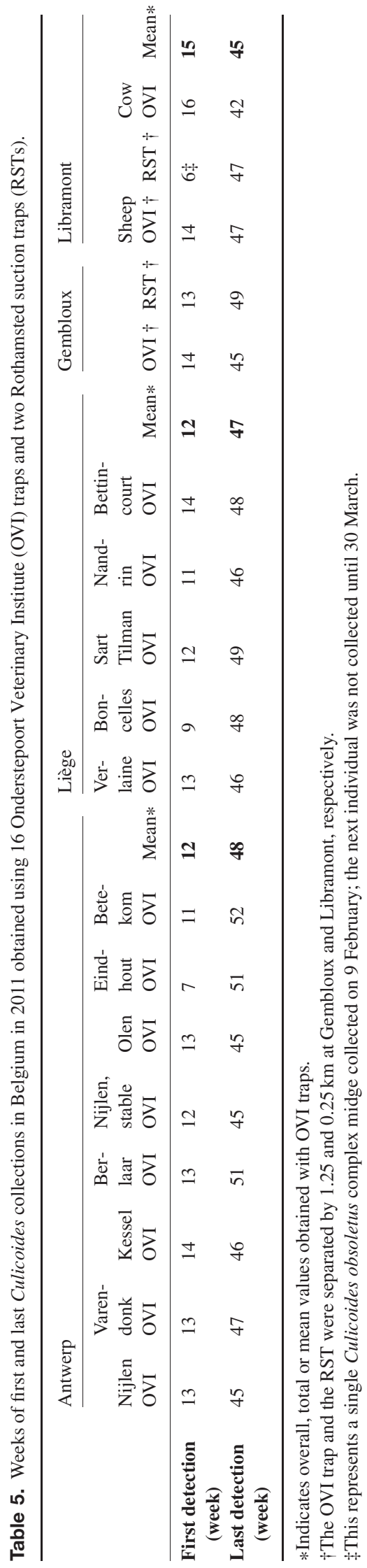

in Belgium and are, moreover, present for most of the year. These results are in agreement with findings in other European countries (Casati et al., 2009; Hoffmann et al., 2009; Kaufmann et al., 2009, 2012; Kiel et al., 2009; Nielsen et al., 2010; Sanders et al., 2011; Silbermayr et al., 2011; Ander et al., 2012; Purse etal., 2012) and emphasize the potentially high vector capacity of these species. Consequently, once introduced, arboviruses for which these species have vectorial competence will spread rapidly over large regions of Europe when hosts and appropriate environmental conditions are present. Interestingly, these species have been previously identified as putative vectors of BTV (De Liberato etal., 2005; Savini et al., 2005; Mehlhorn etal., 2007; Meiswinkel et al., 2007; Dijkstra et al., 2008; Carpenter et al., 2008a; Vanbinst et al., 2009) and more recently as vectors of SBV (except $C$. pulicaris) (De Regge et al., 2012; Rasmussen etal., 2012; Goffredo et al., 2013; Elbers et al., 2013a, 2013b; Larska et al., 2013a, 2013b), two viruses that have spread across a large part of Europe in a relatively short period.

The monitoring results show that many other species are present, but at lower relative abundances and sometimes only for limited periods of the year. This suggests that these species are less likely to be capable of spreading a vector-borne disease over a large area if they represent the sole competent vector present. Just as our knowledge regarding the biology (e.g. host preferences, breeding sites, activity patterns, etc.) of these less abundant species is rather limited, we also know little about their vector competence because all studies on arbovirus detection in field-collected midges focus strongly on the abundant species. Future studies are therefore necessary to address these aspects.

Factors such as climate, temperature, altitude, soil type and land cover are described as influencing the abundance and distribution of midges (Conte etal., 2007; Mehlhorn etal., 2009; Kirkeby etal., 2010; Pérez etal., 2012). In general, these seem to be applicable to observations recorded during the monitoring in Belgium. Belgium has a temperate maritime climate influenced by the North Sea and Atlantic Ocean, with cool summers and moderate winters ( $\mathrm{Cfb}$ climate, Köppen-Geiger classification). The relatively high numbers of Culicoides collected with OVI traps in 2011 compared with previous years (data not shown) can probably be explained by the high average temperatures of 2011, which was the hottest year ever recorded in Belgium (www.meteo.be/meteo/ view/nl/7609555-2011.html). The peak in the number of Culicoides collected at week 19 at all sites followed a period of exceptionally high day and night temperatures at the end of April (www.meteo.be/meteo/view/nl/5688544-April+2011.html). In the central and southern parts of the country, midge activity starts about $2-3$ weeks later than in the east and northeast regions. This reflects the higher altitudes and associated lower temperatures in these places. Further, the sandy soil type of the northeast favours the earlier maturation of midge larvae because these soils warm up more easily during sunny days in early spring. The differences observed in the probability of collecting high numbers of Culicoides at different locations in the region of Liège may derive from the fact that the locations at which monitoring was carried out do not all belong within the same ecoregion. Bettincourt and Verlaine are situated in the loam region, which is characterized as an open agricultural region, whereas Boncelles, 

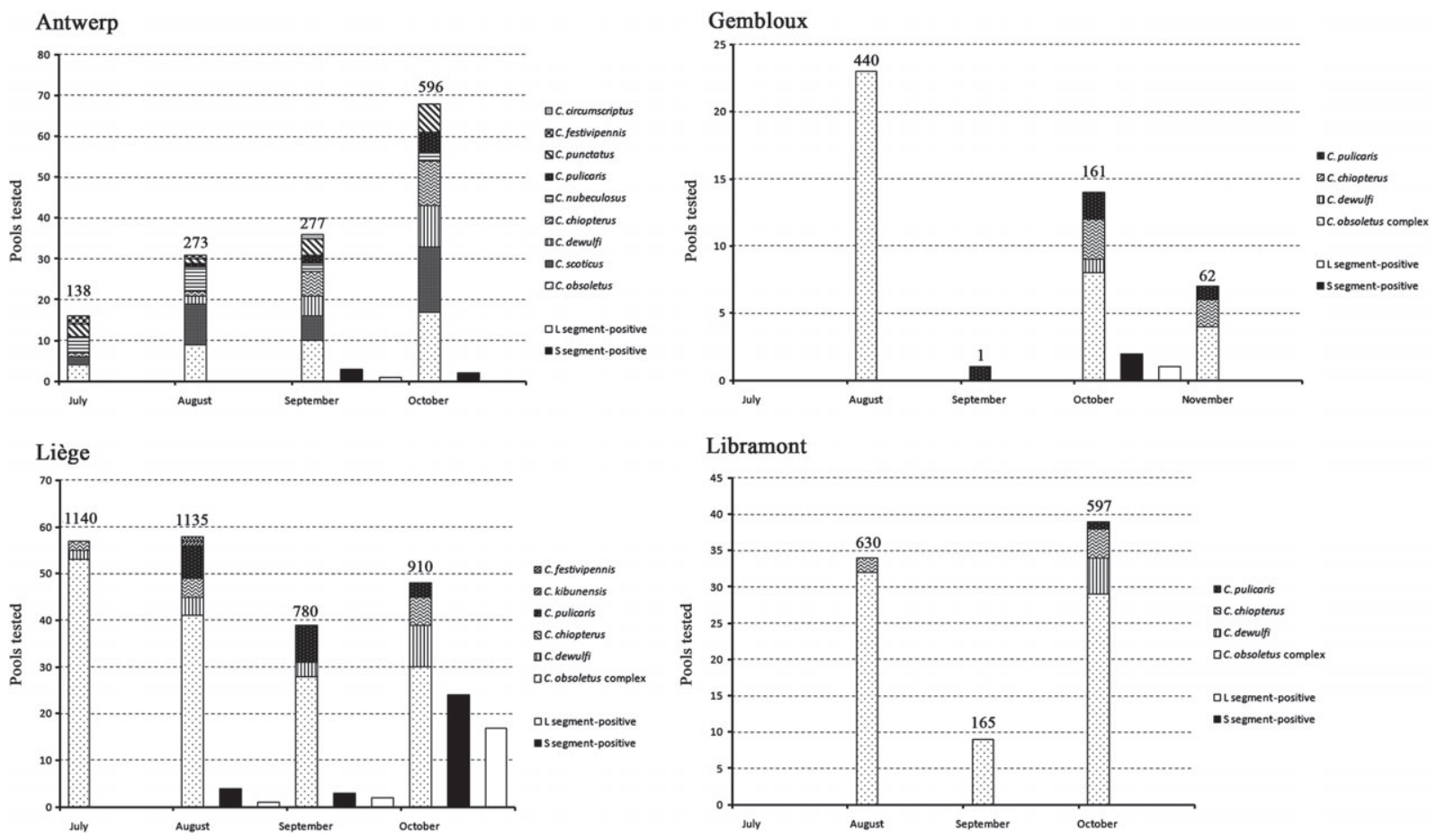

Fig. 3. Findings in pools of Culicoides heads originating from four regions in Belgium in 2011 tested for the presence of Schmallenberg virus (SBV) by real-time reverse-transcription polymerase chain reaction. Numbers above the bars indicate the exact numbers of Culicoides tested.

Sart Tilman and Nandrin are located in the Condroz. The latter consists of a patchwork of prairies and mostly deciduous forests (National Committee of Geography, 2012). These forests may provide suitable breeding sites for Culicoides, especially for the highly abundant $C$. obsoletus complex species, which are known to prefer forest habitats and shaded breeding sites (Kettle, 1962; Conte etal., 2007). Ecological parameters also have important impact on species diversity. For example, species distribution in the bogs of a Belgian nature reserve (Zimmer et al., 2013) was completely different from that found at trapping locations where livestock were present. Proximity to livestock has also been reported as an important factor influencing the number of Culicoides collected (Kaufmann et al., 2009; Tschuor et al., 2009; Aybar et al., 2010; Venter et al., 2011). However, in the present study, no clear correlation was found between the presence of horses or other (combinations of) hosts at collection locations and the probability of collecting large numbers of Culicoides with OVI traps.

The high variability in species abundance, seasonality and species diversity at individual, even nearby, locations is an important finding of this study because it shows that the outcome of vector monitoring programmes can be substantially influenced by the selection of trapping locations. Previous authors have reported that abundance data obtained with one light trap should not be generalized to a large area (Kirkeby et al., 2013). In order to analyse whether the variation observed between sites is consistent over several years, it would be interesting to obtain monitoring data at fixed locations for several vector seasons. Interestingly, the variation observed at individual collection sites was lost when parameters were analysed at regional level.
The selection of collection sites becomes even more important when monitoring results are used for decision making. One of the most relevant reasons for installing Culicoides monitoring in several European countries after the BTV-8 outbreak of 2006 was to define a vector-free period. Our results show that in Belgium in 2011, this period was limited to January. Although regional differences were observed, it is impossible to take these into account in national regulations. To accommodate local variation or the accidental presence of only a limited number of Culicoides, a minimal presence of five parous Culicoides in a trap as described in the EC legislation 2007/1266 was used as a criterion for offical declariation of vector free periods. As this legislation mentions, in addition to the requirement for a sufficient number of vectors to allow virus transmission, environmental temperature should also be taken into account because this factor influences whether or not virus replication will take place in the vector (Mellor et al., 2000; Carpenter et al., 2011). The observed variation between individual trapping locations in this study and the associated potential influence on decision making suggests the need to define criteria for trap types and trapping locations that can be used for legislative purposes, and indicates that current data on vector-free periods should be interpreted with care.

Earlier reported differences between trap types (Fassotte et al., 2008; Carpenter et al., 2008b; Gerry et al., 2009; Venter et al., 2009) are also reflected in our results. Collections obtained by OVI traps at animal level are generally more abundant than those of RSTs obtained at a height of $12 \mathrm{~m}$. However, the use of ultraviolet (UV) light as an attractant in OVI traps can bias the relative abundances of several species. For example, 
Table 6. Detailed overview of pools of Culicoides heads found to be positive for Schmallenberg virus by real-time reverse-transcription polymerase chain reaction.

\begin{tabular}{|c|c|c|c|c|c|}
\hline \multirow[b]{2}{*}{ Location } & \multirow[b]{2}{*}{ Culicoides species } & \multirow[b]{2}{*}{ Collection date } & \multicolumn{3}{|c|}{$\mathrm{Ct}$ value } \\
\hline & & & IC & L segment & S segment \\
\hline \multicolumn{6}{|l|}{ Antwerp } \\
\hline Betekom & C. obsoletus & 7 Sept 2011 & 31.7 & 37.00 & 34.90 \\
\hline Eindhout & C. obsoletus & 20 Sept 2011 & 16.3 & Negative & 36.45 \\
\hline Berlaar & C. obsoletus & 6 Sept 2011/20 Sept 2011 & 17.6 & Negative & 36.31 \\
\hline Betekom & C. pulicaris & 7 Sept $2011 / 4$ Oct 2011 & 14.3 & Negative & 37.90 \\
\hline Betekom & C. dewulfi & 4 Oct 2011 & 16.7 & Negative & 38.10 \\
\hline \multicolumn{6}{|l|}{ Liège } \\
\hline Boncelles & C. obsoletus complex & 10 Aug 2011 & 15.09 & Negative & 35.41 \\
\hline Sart Tilman & C. obsoletus complex & 23 Aug 2011 & 18.94 & Negative & 35.25 \\
\hline Bettincourt & C. obsoletus complex & 23 Aug 2011 & 18.09 & Negative & 35.96 \\
\hline Bettincourt & C. dewulfi & 23 Aug 2011 & 17.11 & 34.12 & 32.21 \\
\hline Boncelles & C. obsoletus complex & 25 Sept 2011 & 17.96 & 32.81 & 30.70 \\
\hline Nandrin & C. obsoletus complex & 25 Sept 2011 & 17.05 & Negative & 33.47 \\
\hline Nandrin & C. obsoletus complex & 25 Sept 2011 & 17.59 & 33.48 & 32.32 \\
\hline Verlaine & C. obsoletus complex & 5 Oct 2011 & 24.82 & 32.28 & 31.49 \\
\hline Boncelles & C. obsoletus complex & 5 Oct 2011 & 26.78 & 33.66 & 34.78 \\
\hline Boncelles & C. obsoletus complex & 5 Oct 2011 & 26.67 & 33.67 & 32.51 \\
\hline Sart Tilman & C. obsoletus complex & 5 Oct 2011 & 31.92 & Negative & 37.79 \\
\hline Sart Tilman & C. obsoletus complex & 5 Oct 2011 & 30.53 & 34.12 & 37.49 \\
\hline Sart Tilman & C. obsoletus complex & 5 Oct 2011 & 27.24 & Negative & 38.20 \\
\hline Sart Tilman & C. obsoletus complex & 5 Oct 2011 & 29.12 & 32.05 & 30.94 \\
\hline Sart Tilman & C. obsoletus complex & 5 Oct 2011 & 30.01 & Negative & 38.31 \\
\hline Sart Tilman & C. obsoletus complex & 5 Oct 2011 & 30.75 & 35.08 & 36.22 \\
\hline Sart Tilman & C. obsoletus complex & 5 Oct 2011 & 29.22 & Negative & 38.52 \\
\hline Sart Tilman & C. dewulfi & 5 Oct 2011 & 24.69 & Negative & 38.36 \\
\hline Sart Tilman & C. dewulfi & 5 Oct 2011 & 29.02 & 31.97 & 30.69 \\
\hline Sart Tilman & C. dewulfi & 5 Oct 2011 & 26.63 & Negative & 38.10 \\
\hline Sart Tilman & C. dewulfi & 5 Oct 2011 & 29.68 & Negative & 38.33 \\
\hline Nandrin & C. obsoletus complex & 14 Oct 2011 & 21.63 & 29.80 & 28.07 \\
\hline Verlaine & C. obsoletus complex & 28 Oct 2011 & 26.96 & 30.56 & 30.05 \\
\hline Verlaine & C. obsoletus complex & 28 Oct 2011 & 20.95 & 27.95 & 27.87 \\
\hline Verlaine & C. obsoletus complex & 28 Oct 2011 & 26.09 & 30.36 & 30.56 \\
\hline Nandrin & C. obsoletus complex & 28 Oct 2011 & 24.02 & 29.66 & 28.62 \\
\hline Nandrin & C. obsoletus complex & 28 Oct 2011 & 24.58 & 28.60 & 27.48 \\
\hline Nandrin & C. obsoletus complex & 28 Oct 2011 & 24.28 & 31.39 & 30.81 \\
\hline Nandrin & C. obsoletus complex & 28 Oct 2011 & 24.62 & 32.80 & 33.16 \\
\hline Nandrin & C. obsoletus complex & 28 Oct 2011 & 23.47 & 33.37 & 35.17 \\
\hline Bettincourt & C. chiopterus & 28 Oct 2011 & 25.76 & 29.49 & 28.69 \\
\hline Gembloux & C. obsoletus complex & 4 Oct 2011 & 16.06 & Negative & 35.35 \\
\hline Gembloux & C. obsoletus complex* & 11 Oct 2011 & 16.22 & 30.65 & 26.65 \\
\hline
\end{tabular}

$*$ Blood and eggs.

IC, internal control.

the relative abundances of C.pulicaris and C.chiopterus are probably underestimated with OVI traps because these species are, respectively, active during the afternoon before sunset (Goetghebuer, 1919) or are less attracted by UV light (Carpenter et al., 2008b). This is confirmed by the higher relative abundances of both these species in collections obtained with RSTs, which passively collect Culicoides throughout the day at a height of $12 \mathrm{~m}$. Despite the fact that RSTs collect midges from a different niche of the Culicoides population and that only low numbers of midges were collected in these traps compared with OVI traps, 29 different species were identified, including C. riouxi, which was not collected by OVI traps.
The midge collections obtained during 2011 also represent ideal material for the study of several aspects of the epidemiology of SBV. Data on the rRT-PCR detection of SBV in a limited number of pools (representing 1976 midges) from Antwerp and Liège originating from the 2011 monitoring in Belgium have been published previously (De Regge et al., 2012) and indicate that SBV was detected in the heads of C.obsoletus complex, C. dewulfi and C.chiopterus midges. In the present study, an extra 5400 Culicoides, some of which originated from an additional six locations, were tested, but no additional putative vector species were found. Only one of the 31 pools of $C$.pulicaris tested was positive for the S segment of SBV. However, as this 
Table 7. Numbers and percentages of pools positive for Schmallenberg virus $\mathrm{S}$ segment RNA by location in the region of Liège collected during August-October 2011.

\begin{tabular}{lllll}
\hline & $\begin{array}{l}\text { Pools } \\
\text { tested, } n\end{array}$ & $\begin{array}{l}\text { Pools } \\
\text { negative, } n\end{array}$ & $\begin{array}{l}\text { Pools } \\
\text { positive, } n\end{array}$ & $\begin{array}{l}\text { Positivity, } \\
\%\end{array}$ \\
\hline Verlaine & 27 & 23 & 4 & 15 \\
Boncelles & 28 & 24 & 4 & 14 \\
Sart Tilman & 41 & 29 & 12 & 29 \\
Nandrin & 33 & 25 & 8 & 24 \\
Bettincourt & 16 & 13 & 3 & 19 \\
\hline
\end{tabular}

pool was negative for the $\mathrm{L}$ segment, the role of this species in the spread of SBV remains questionable.

As discussed previously (De Regge etal., 2012), the fact that the pools examined consisted exclusively of heads is an additional indication that the species found to be positive for the $\mathrm{S}$ and $\mathrm{L}$ segments can act as real amplification vectors because the virus has reached the salivary glands. The $\mathrm{Ct}$ values obtained in the heads are in line with $\mathrm{Ct}$ values found in SBV-infected C. sonorensis midges that have been shown to be orally susceptible to SBV (Veronesi et al., 2013b). Further research will be required to show whether the large range of $\mathrm{Ct}$ values obtained (between 26.6 and 38.5 for the $\mathrm{S}$ segment) reflect differences in the capacity of the virus to replicate in the salivary glands of individual midges or whether this simply reflects the collection of midges at different periods after the bloodmeal.

Published results have already shown findings of SBVpositive midges in Antwerp and in the Liège region, with a high number of SBV-positive pools recorded in the latter region in October (De Regge etal., 2012). This was confirmed by the testing of additional pools originating from other locations in the same region. More than $50 \%$ of pools containing C. obsoletus complex midges were found to be SBV-positive, indicating a minimum infection prevalence of $3.1 \%$ (19/620) in this species in October at Liège, given each positive pool contained one SBV-positive midge. A similar infection prevalence of $3.6 \%$ (3/83) was found in C.obsoletus s.s. midges in September in Antwerp. Despite the higher probability for obtaining larger Culicoides collections at Boncelles, Sart Tilman and Nandrin than at Verlaine and Bettincourt, no significant differences in the number of SBV-positive pools were found between the different sites, indicating that SBV-infected midges were evenly distributed across the Liège region. The results of this study also show that SBV-positive Culicoides were found at Gembloux in the centre of Belgium. However, at Libramont in the south of the country, none of the pools tested positive for SBV. This is probably indicative of a lesser spread of the virus to this part of Belgium, which is characterized by higher altitudes and dense forests. It also correlates with the relatively lower within-herd seroprevalence found in sheep and cows in this region at the end of the vector season of 2011 (Méroc et al., 2013, 2014). The finding of high numbers of SBV-positive midges at Libramont during the vector season of 2012, when the prevalence of infection in Avaritia midges was found to be $2.86 \%$ in August (De Regge et al., 2014), supports this hypothesis.

The rRT-PCR screening of Culicoides for the presence of SBV does not provide any indication of the circulation of SBV in
Belgium prior to August 2011. However, this remains only indicative because a low level of circulation of the virus before August may easily have been missed by this approach. Nevertheless, SBV circulation from August coincides with the period in which regional animal health care centres [Association Régionale de Santé et d'Identification Animales (ARSIA) and Dierengezondheidszorg Vlaanderen (DGZ)] in Belgium began to receive notifications of problems such as milk drop and diarrhoea on cattle farms from which other endemic and epizootic viruses (e.g. bovine viral diarrhoea virus, infectious bovine rhinotracheitis virus, BTV) had been excluded.

The results of the present study underline the variation associated with the collection locations selected and the trap types used, but also show the advantages of a Culicoides monitoring programme. However, the financial aspects of such a scheme make it difficult to justify such extensive yearly monitoring, certainly as Belgium became officially free of BTV in February 2012. Nonetheless, as the odds are high that (re)new(ed) introductions of Culicoides-borne or other vector-borne diseases will occur in the future, it would seem advisable to install a permanent and structural surveillance system, whether or not this functions in rotation with the monitoring of other vectors such as mosquitoes and ticks. This is necessary not only to retain in place expertise related to vector trapping and identification, but particularly to detect the introduction of exotic pathogens and vectors as early as possible and to correctly assess any potential risks to animal and public health associated with potential introductions of arthropod-borne disease.

\section{Acknowledgements}

Monitoring of Culicoides species in Belgium in 2011 was financed by the Belgian Federal Agency for the Safety of the Food Chain (FAVV-AFSCA). Real-time reverse-transcription polymerase chain reaction (rRT-PCR) analysis of Culicoides for the presence of Schmallenberg virus (SBV) was financially supported by the Belgian Federal Public Service 'Public Health and Safety of the Food Chain and Environment' and the European Union as outlined in Council Decision 2012/349/EU concerning a financial contribution by the Union for studies on SBV. We gratefully thank Martin Beer and Bernd Hoffmann, Friedrich Loeffler Institute, Greifswald Insel Riems, Germany, for the provision of primer/probe sequences for SBV detection by rRT-PCR. We thank Marie-Rose Bolen, Plant Protection and Ecotoxicology, Life Science Department, Walloon Agricultural Research Centre (CRA-W), Gembloux, Belgium (Gembloux), and Hughes Seutin and Liliane Deveux, Plant Protection and Ecotoxicology, Life Science Department, Walloon Agricultural Research Centre (CRA-W), Gembloux, Belgium (Libramont) for their help with the collection of midges. We also thank Virginie Colasse, Operational Direction Viral Diseases, Veterinary and Agrochemical Research Centre (CODA-CERVA), Brussels, Belgium, for her excellent help with the rRT-PCR testing of Culicoides, and Flavien Riocreux, Operational Direction Viral Diseases, Veterinary and Agrochemical Research Centre (CODA-CERVA), Brussels, Belgium, for preparing the map of Culicoides trapping locations. 


\section{References}

Al-Busaidy, S.M. \& Mellor, P.S. (1991) Isolation and identification of arboviruses from the Sultanate of Oman. Epidemiology and Infection, 106, 403-413.

Ander, M., Meiswinkel, R. \& Chirico, J. (2012) Seasonal dynamics of biting midges (Diptera: Ceratopogonidae: Culicoides), the potential vectors of bluetongue virus, in Sweden. Veterinary Parasitology, 184, $59-67$.

Aybar, C.A., Juri, M.J., De Grosso, M.S. \& Spinelli, G.R. (2010) Species diversity and seasonal abundance of Culicoides biting midges in northwestern Argentina. Medical and Veterinary Entomology, 24, 95-98.

Berisha, B., Goga, I., Hulaj, B., Çaushi, D., Sherifi, K., Wilsmore, A.J. \& Taylor, W.P. (2010) Entomological research on the vectors of bluetongue disease and the monitoring of activity of Culicoides in the Prishtinë region of Kosova. Veterinaria Italiana, 46, 431-437.

Bryant, J.E., Crabtree, M.B., Nam, V.S., Yen, N.T., Duc, H.M. \& Miller, B.R. (2005) Isolation of arboviruses from mosquitoes collected in northern Vietnam. American Journal of Tropical Medicine and Hygiene, 73, 470-473.

Carpenter, S., McArthur, C., Selby, R. etal. (2008a) Experimental infection studies of UK Culicoides species midges with bluetongue virus serotypes 8 and 9. Veterinary Record, 163, 589-592.

Carpenter, S., Szmaragd, C., Barber, J., Labuschagne, K., Gubbins, S. \& Mellor, P.S. (2008b) An assessment of Culicoides surveillance techniques in northern Europe: have we underestimated a potential bluetongue virus vector? Journal of Applied Ecology, 45, 1237-1245.

Carpenter, S., Wilson, A., Barber, J., Veronesi, E., Mellor, P., Venter, G.J. \& Gubbins, S. (2011) Temperature dependence of the incubation period of orbiviruses in Culicoides biting midges. PLoS One, 6, e27987.

Casati, S., Racloz, V., Delécolle, J.C. etal. (2009) An investigation on the Culicoides species composition at seven sites in southern Switzerland. Medical and Veterinary Entomology, 23, 93-98.

Chaintoutis, S.C., Kiossis, E., Giadinis, N.D. et al. (2014) Evidence of Schmallenberg virus circulation in ruminants in Greece. Tropical Animal Health and Production, 46, 251-255.

Conraths, F.J., Peters, M. \& Beer, M. (2013) Schmallenberg virus, a novel orthobunyavirus infection in ruminants in Europe: potential global impact and preventive measures. New Zealand Veterinary Journal, 61, 63-67.

Conte, A., Goffredo, M., Ippoliti, C. \& Meiswinkel, R. (2007) Influence of biotic and abiotic factors on the distribution and abundance of Culicoides imicola and the Obsoletus complex in Italy. Veterinary Parasitology, 150, 333-344.

De Deken, G., Madder, M., Deblauwe, I. et al. (2008) Vector monitoring at Belgian outbreak sites during the bluetongue epidemic of 2006. Preventive Veterinary Medicine, 87, 64-73.

Delécolle, J.C. (1985) Nouvelle contribution à l'étude systématique et iconographique des espèces du genre Culicoides (Diptera: Ceratopogonidae) du nord-est de la France. PhD Thesis. University of Strasbourg, Strasbourg.

De Liberato, C., Scavia, G., Lorenzetti, R. et al. (2005) Identification of Culicoides obsoletus (Diptera: Ceratopogonidae) as a vector of bluetongue virus in central Italy. Veterinary Record, 156, 301-304.

De Regge, N., Deblauwe, I., De Deken, R. etal. (2012) Detection of Schmallenberg virus in different Culicoides spp. by real time RT-PCR. Transboundary and Emerging Diseases, 59, 471-475.

De Regge, N., Madder, M., Deblauwe, I. et al. (2014) Schmallenberg virus circulation in Culicoides in Belgium in 2012: field validation of a real time RT-PCR approach to assess virus replication and dissemination in midges. PLoS One, 9, e87005.

Dijkstra, E., van der Ven, I.J., Meiswinkel, R., Hölzel, D.R., van Rijn, P.A. \& Meiswinkel, R. (2008) Culicoides chiopterus as a potential vector of bluetongue virus in Europe. Veterinary Record, 162, 422.

Doceul, V., Lara, E., Sailleau, C. et al. (2013) Epidemiology, molecular virology and diagnostics of Schmallenberg virus, an emerging orthobunyavirus in Europe. Veterinary Research, 44, 31.

Elbers, A.R., Meiswinkel, R., van Weezep, E., van Oldruitenborgh-Oosterbaan, M.M. \& Kooi, E.A. (2013a) Schmallenberg virus in Culicoides spp. biting midges, the Netherlands, 2011. Emerging and Infectious Diseases, 19, 106-109.

Elbers, A.R., Meiswinkel, R., van Weezep, E., Kooi, E.A., van der Poel, W.H. (2013b) Schmallenberg virus in Culicoides biting midges in the Netherlands in 2012. Transboundary and Emerging Diseases, doi: 10.1111/tbed.12128 [Epub ahead of print].

European Food Safety Authority (2013) 'Schmallenberg' virus: analysis of the epidemiological data. Supporting Publications 2013: EN-429. www.efsa.europa.eu/publications [accessed on 13 May 2014].

Fassotte, C., Delécolle, J.C., Cors, R., Defrance, T., De Deken, R., Haubruge, E. \& Losson, B. (2008) Culicoides trapping with Rothamsted suction traps before and during the bluetongue epidemic of 2006 in Belgium. Preventive Veterinary Medicine, 87, 74-83.

Gerry, A.C., Sarto, I., Monteys, V., Moreno Vidal, J.O., Francino, O. \& Mullens, B.A. (2009) Biting rates of Culicoides midges (Diptera: Ceratopogonidae) on sheep in northeastern Spain in relation to midge capture using UV light and carbon dioxide-baited traps. Journal of Medical Entomology, 46, 615-624.

Goetghebuer, M. (1919) Métamorphoses et moeurs du Culicoides pulicaris. Bulletin Annales de la Societé Entomologique de Belgique, 59, 25-30.

Goffredo, M., Monaco, F., Capelli, G. et al. (2013) Schmallenberg virus in Italy: a retrospective survey in Culicoides stored during the bluetongue Italian surveillance program. Preventive Veterinary Medicine, 111, 230-236.

Hoffmann, B., Bauer, B., Bauer, C. et al. (2009) Monitoring of putative vectors of bluetongue virus serotype 8, Germany. Emerging and Infectious Diseases, 15, 1481-1484.

Hoffmann, B., Scheuch, M., Höper, D. etal. (2012) Novel orthobunyavirus in cattle, Europe, 2011. Emerging and Infectious Diseases, 18, 469-472.

Hörbrand, T. \& Geier, M. (2009) Monitoring of Culicoides at nine locations in southern Germany (2007-2008). Parasitology Research, $\mathbf{1 0 5}, 387-392$.

Johnson, N., Voller, K., Phipps, L.P., Mansfield, K. \& Fooks, A.R. (2012) Rapid molecular detection methods for arboviruses of livestock of importance to northern Europe. Journal of Biomedicine and Biotechnology, 2012, 719402.

Kaufmann, C., Schaffner, F. \& Mathis, A. (2009) Monitoring of biting midges (Culicoides spp.), the potential vectors of the bluetongue virus, in the 12 climatic regions of Switzerland. Schweizer Archiv für Tierheilkunde Gesellschaft Schweizerischer Tierärzte, 151, 205-213.

Kaufmann, C., Steinmann, I.C., Hegglin, D., Schaffner, F. \& Mathis, A. (2012) Spatio-temporal occurrence of Culicoides biting midges in the climatic regions of Switzerland, along with large scale species identification by MALDI-TOF spectrometry. Parasites and Vectors, $\mathbf{5}, 246-255$.

Kettle, D.S. (1962) The bionomics and control of Culicoides and Leptoconops (Diptera, Ceratopogonidae $=$ Heleidae). Annual Review of Entomology, 7, 401-418. 
Kiel, E., Liebisch, G., Focke, R., Liebisch, A. \& Werner, D. (2009) Monitoring of Culicoides at 20 locations in northwest Germany. Parasitology Research, 105, 351-357.

Kirkeby, C., Bodker, R., Stockmarr, A. \& Enoe, C. (2010) Association between land cover and Culicoides (Diptera: Ceratopogonidae) breeding sites in four Danish cattle farms. Entomologica Fennica, 20, 228-232.

Kirkeby, C., Stockmarr, A., Bodker, R. \& Lind, P. (2013) Spatiotemporal optimization of sampling for bluetongue vectors (Culicoides) near grazing livestock. Parasites and Vectors, 6, 151.

Larska, M., Lechowski, L., Grochowska, M. \& Zmudziński, J.F. (2013a) Detection of the Schmallenberg virus in nulliparous Culicoides obsoletus/scoticus complex and C. punctatus. The possibility of transovarial virus transmission in the midge population and of a new vector. Veterinary Microbiology, 166, 467-473.

Larska, M., Polak, M.P., Grochowska, M., Lechowski, L., Związek, J.S. \& Zmudziński, J.F. (2013b) First report of Schmallenberg virus infection in cattle and midges in Poland. Transboundary and Emerging Diseases, 60, 97-101.

Macaulay, E.D.M., Tatchell, G.M. \& Taylor, L.R. (1988) The Rothamsted insect survey '12-metre' suction trap. Bulletin of Entomological Research, 78, 121-129.

Mehlhorn, H., Walldorf, V., Klimpel, S. et al. (2007) First occurrence of Culicoides obsoletus-transmitted bluetongue virus epidemic in central Europe. Parasitology Research, 101, 219-228.

Mehlhorn, H., Walldorf, V., Klimpel, S. et al. (2009) Bluetongue disease in Germany (2007-2008): monitoring of entomological aspects. Parasitology Research, 105, 313-319.

Meiswinkel, R., van Rijn, P., Leijs, P. \& Goffredo, M. (2007) Potential new Culicoides vector of bluetongue virus in northern Europe. Veterinary Record, 161, 564-565.

Meiswinkel, R., Baldet, T., De Deken, R., Takken, W., Delécolle, J.C. \& Mellor, P.S. (2008a) The 2006 outbreak of bluetongue in northern Europe - the entomological perspective. Preventive Veterinary Medicine, 87, 55-63.

Meiswinkel, R., Goffredo, M., Leijs, P. \& Conte, A. (2008b) The Culicoides 'snapshot': a novel approach used to assess vector densities widely and rapidly during the 2006 outbreak of bluetongue (BT) in the Netherlands. Preventive Veterinary Medicine, 87, 98-118.

Mellor, P.S., Boorman, J. \& Baylis, M. (2000) Culicoides biting midges: their role as arbovirus vectors. Annual Review of Entomology, 45, 307-340.

Méroc, E., Poskin, A., van Loo, H. etal. (2013) Large-scale cross-sectional serological survey of Schmallenberg virus in Belgian cattle at the end of the first vector season. Transboundary and Emerging Diseases, 60, 4-8.

Méroc, E., De Regge, N., Riocreux, F., Caij, A.B., van den Berg, T. \& van der Stede, Y. (2014) Distribution of Schmallenberg virus and seroprevalence in Belgian sheep and goats. Transboundary and Emerging Diseases, 61, 425-431.

National Committee of Geography (2012) A Concise Geography of Belgium. Academia Press, Ghent \& Press Point, Merelbeke. http://www. atlas-belgique.be/ACGoB.pdf [accessed on 14 May 2014].

Nielsen, S.A., Nielsen, B.O. \& Chirico, J. (2010) Monitoring of biting midges (Diptera: Ceratopogonidae: Culicoides Latreille) on farms in Sweden during the emergence of the 2008 epidemic of bluetongue. Parasitology Research, 106, 1197-1203.

Pérez, J.M., García-Ballester, J.A., López-Olvera, J.R. \& Serrano, E. (2012) Monitoring bluetongue virus vectors in Andalusia (SW Europe): Culicoides species composition and factors affecting capture rates of the biting midge Culicoides imicola. Parasitology Research, 111, 1267-1275.

Purse, B.V., Falconer, D., Sullivan, M.J. et al. (2012) Impacts of climate, host and landscape factors on Culicoides species in Scotland. Medical and Veterinary Entomology, 26, 168-177.

Rasmussen, L.D., Kristensen, B., Kirkeby, C., Rasmussen, T.B., Belsham, G.J., Bødker, R. \& Bøtner, A. (2012) Culicoids as vectors of Schmallenberg virus. Emerging and Infectious Diseases, 18, 1204-1206.

Sanders, C.J., Shortall, C.R., Gubbins, S. et al. (2011) Influence of season and meteorological parameters on flight activity of Culicoides biting midges. Journal of Applied Ecology, 48, 1355-1364.

Savini, G., Goffredo, M., Monaco, F. et al. (2005) Bluetongue virus isolations from midges belonging to the Obsoletus complex (Culicoides, Diptera: Ceratopogonidae) in Italy. Veterinary Record, 157, 133-139.

Silbermayr, K., Hackländer, K., Doscher, C., Koefer, J. \& Fuchs, K. (2011) A spatial assessment of Culicoides spp. distribution and bluetongue disease risk areas in Austria. Berliner und Münchener Tierärztliche Wochenschrift, 124, 228-235.

St George, T.G., Standfast, H.A. \& Cybinski, D.H. (1978) Isolations of akabane virus from sentinel cattle and Culicoides brevitarsis. Australian Veterinary Journal, 54, 558-561.

Tschuor, A.C., Kaufmann, C., Schaffner, F. \& Mathis, A. (2009) Occurrence of biting midges (Culicoides spp.) at three different altitudes in an alpine region of Switzerland. Schweizer Archiv für Tierheilkunde Gesellschaft Schweizerischer Tierärzte, 151, 215-221.

Vanbinst, T., Vandenbussche, F., Vandemeulebroucke, E. et al. (2009) Bluetongue virus detection by real-time RT-PCR in Culicoides captured during the 2006 epizootic in Belgium and development of an internal control. Transboundary and Emerging Diseases, 56, 170-177.

Venter, G.J., Labuschagne, K., Hermanides, K.G., Boikanyo, S.N.B., Majatladi, D.M. \& Morey, L. (2009) Comparison of the efficiency of five suction light traps under field conditions in South Africa for the collection of Culicoides species. Veterinary Parasitology, 166, 299-307.

Venter, G.J., Labuschagne, K., Boikanyo, S.N., Majatladi, D.M. \& Morey, L. (2011) The effect of 1-octen-3-ol and 4-methylphenol on Culicoides midge numbers collected with suction light traps in South Africa. Veterinary Parasitology, 175, 182-186.

Veronesi, E., Antony, F., Gubbins, S. et al. (2013a) Measurement of the infection and dissemination of bluetongue virus in Culicoides biting midges using a semi-quantitative rt-PCR assay and isolation of infectious virus. PLoS One, $\mathbf{8}$, e70800.

Veronesi, E., Henstock, M., Gubbins, S. etal. (2013b) Implicating Culicoides biting midges as vectors of Schmallenberg virus using semi-quantitative RT-PCR. PLoS One, 8, e57747.

Vorsprach, B., Meiser, C.K., Werner, D., Balczun, C. \& Schaub, G.A. (2009) Monitoring of Ceratopogonidae in southwest Germany. Parasitology Research, 105, 337-344.

Yanase, T., Kato, T., Kubo, T. etal. (2005) Isolation of bovine arboviruses from Culicoides biting midges (Diptera: Ceratopogonidae) in southern Japan: 1985-2002. Journal of Medical Entomology, 42, 63-67.

Zimmer, J.Y., Smeets, F., Simonon, G., Fagot, J., Haubruge, E., Francis, F. \& Losson, B. (2013) Are bogs reservoirs for emerging disease vectors? Evaluation of Culicoides populations in the Hautes Fagnes Nature Reserve (Belgium). PLoS One, 8, e66893.

Accepted 4 December 2014

First published online 11 March 2015 